(FY 84 First

Quarter)

Interim Report

Chemical Species of Migrating

Radionuclides at Commercial

Shallow Land Burial Sites

Quarterly Progress Report

October-December, 1983

L. J. Kirby

W. H. Rickard

A. P. Toste

February 1984

Prepared for the

U.S. Nuclear Regulatory Commission

under Contract DE-AC 06-76RLO-1830

NRC FIN B2291

Pacific Northwest Laboratory

Operated for the U.S. Department of Energy

by Battelle Memorial Institute 


\title{
DISCLAIMER
}

This report was prepared as an account of work sponsored by an agency of the United States Government. Neither the United States Government nor any agency thereof, nor any of their employees, makes any warranty, express or implied, or assumes any legal liability or responsibility for the accuracy, completeness, or usefulness of any information, apparatus, product, or process disclosed, or represents that its use would not infringe privately owned rights. Reference herein to any specific commercial product, process, or service by trade name, trademark, manufacturer, or otherwise, does not necessarily constitute or imply its endorsement, recommendation, or favoring by the United States Government or any agency thereof. The views and opinions of authors expressed herein do not necessarily state or reflect those of the United States Government or any agency thereof.

\author{
PACIFIC NORTHWEST LABORATORY \\ operated by \\ BATTELLE \\ for the \\ UNITED STATES DEPARTMENT OF ENERGY \\ under Contract DE-AC06-76RLO 1830
}


PNL $-4432-7$

(FY 84 FIRST

QUARTER)

\section{INTERIM REPORT}

CHEMICAL SPECIES OF MIGRATING

RADI ONUCL IDES AT COMMERCIAL

SHALLOW LAND BURIAL SITES

QUARTERL Y PROGRESS REPORT

October-December, 1983

L. J. Kirby

W. H. Rickard

A. P. Toste

February, 1984

Prepared for the

U.S. Nuclear Regulatory Commission under Contract OE-ACO6-76RL 0-1830

NRC FIN B2291

Pacific Northwest $L$ aboratory

Richl and, Washington 99352 



\section{PREFACE}

This is the seventh quarterly report for the project "Chemical Species of Migrating Radionuclides at Commercial Shallow Land Burial Sites" (NRC FIN 82291) under a reporting schedule initiated in mid-1982. The next report is scheduled in Apri1, 1984.

The project task organization has undergone several revisions since this reporting schedule was established. To assist the reader to follow the progress of the research, as each new report is prepared we are summarizing previously reported research under a section titied "Summary of Prior Efforts."

Detailed reporting of research findings will continue to be published in quarterly, topical and annual reports and in the open literature. 


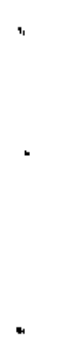

. 


\section{EXECUT IVE SLMMARY}

The primary purpose of this project is to develop an understanding of chemical processes that significantly influence the migration of radionuclides at comercial low-level waste (LLW) burial sites. Chemical measurements of waste trench leachate and identification of chemical changes in leachate during migration will provide a bas is for geochemical waste transport models. This project will produce for the U.S. Nuclear Regul atory Commission (NRC) information to support guidance for implementation of 10 CFR 61, particularly in the development of criteria for low level waste disposal site selection, management, permanent closure and monitoring. This project will al so produce information needed by the Commonwealth of Kentucky as they finalize plans to stabilize, close and monitor the Maxey Flats site.

Chemical Forms: I norganic and Organic Radionuclide Species

Camprehensive organic analyses performed on Maxey Flats waste trench leachate, water from the experimental trench and water from the inert atmosphere wells have determined a large number of hydrophilic and hydrophobic organic compounds in these waters. Analys is of the field-separated solutions fram chromatographically fractionated water samples has revealed a complex pattern of as sociation between radionuclides and organic campounds in these waters.

Ethylenediaminetetraacetic acid (EDTA) is a major organic compound in water from waste trench leachates and in water from inert atmosphere well W2NA and evidence points to the migration of plutonium short distances within the site as an EDTA complex. Polar organic compounds (e.g. palmitic and stearic acids) may influence the migration of ${ }^{90} \mathrm{Sr}$ and ${ }^{137} \mathrm{Cs}$.

Six classes of hydrophilic organic compounds are present in the waste trench leachates: synthetic chelating agents containing ethylenediamine as a core; dicarboxylic acids; monocarboxylic acids; oxygenated carboxylic acids; aramatic carboxylic acids; and phthalic acid esters. The chelating agents are typically used in decontamination operations at nuclear facilities. The four classes of carboxylic 
acids are common bioorganic compounds or their microbial diagenes is products. Phthalates are used heavily in industry as plasticizers and may also be microbial diagenes is products.

The most abundant hydrophilic organic compounds identified in the waste leachates are the chelating agents, ranging from 22.9 ppm in trench $19 \mathrm{~W}$ down to $0.08 \mathrm{ppm}$ in waste trench $33 \mathrm{~L}-8$. Three chel ating agents were identified in the leachates: ethylenediaminetetraacetic acid (EDTA), N-hydroxyethylethylenediaminetriacetic acid (HEDTA), and ethylenediaminetriacetic acid (ED3A). EUTA is common to al 1 of the leachates over a wide range of concentrations, ranging fran 12.4 ppm to trench $19 \mathrm{~W}$ down to $0.08 \mathrm{ppm}$ in trench $33 \mathrm{~L}-8$. EDTA is the most abundant chelating agent in the leachates, with the exception of trench $23 \mathrm{M}$ where HEDTA is most abundant. The relative abundance of EDTA in the leachates varies considerably: it constitutes $81 \%$ of the chelating agent pool in trench $7-3$; 54\% in trench $19 \mathrm{~W}$; $71 \%$ in trench 19S; a low $17.3 \%$ in trench $23 \mathrm{M}$; $82 \%$ in trench 27 ; and $100 \%$ in trenches $33 \mathrm{~L}-4$, $33 L-8$ and 35 . These differences undoubtedly reflect differences in the wastes originally buried, as well as differences in the microbial and/or chemical environments of the waste trenches.

Overall, HEDTA is the second most abundant chelating agent in the waste trenches. In trench $23 M$ it is the most abundant hydrophilic organic compound at $19.5 \mathrm{pm}$. This value is actually the highest for any of the chelating agents. An unusually high concentration of ED3A is also present in waste trench $23 M$ and may be derived from the degradation of HEDTA.

Analys is of the hydrophobic organic compounds that were isolated to facilitate the chromatographic analys is of hydrophilic organic species has also permitted us to obtain information on toxic organic compounds that are present in these waters. The hydrophobic organic compounds identified in the waste leachates from Maxey Flats are generally at much lower concentrations than those of the hydrophilic organic compounds (ppb vs ppm). A number of the compounds, e.g., the halogenated hydrocarbons, are toxic and, therefore, of potential 
environmental concern. Their concentrations are quite low, however. From a research point of view, some of the hydrophobic organic compounds, e.g., the barbiturates, have been exploited as in-situ, wastederived tracers of groundwater flow.

- Subsurface Migration and Inf iTtration Studies

Well-logging measurments of inert atmosphere wells, experiment al trench sumps, and three four-inch diameter E-series wells have confinmed that waste radionuclide migration along the sandstone marker bed occurred only within the restricted area at Maxey Flats. Cesium$137(0.84 \mathrm{pCi} / \mathrm{gm})$ and ${ }^{\circ} \mathrm{Co}(0.54 \mathrm{pC} \mathrm{i} / \mathrm{gm})$ were measured in well $14 \mathrm{E}$ on the Maxey Flats site at the top of the sandstone marker bed, or about 6.1 meters (20 feet) below the ground surface. Strontium-90 is also present at or below the detection limit (10 $\mathrm{pCi} / \mathrm{gm}$ or 1 ess).

Anays is of composited water samples from selected $E$-series wells around the Maxey $F$ lats site has revealed that only tritiun is present in significant quantities; ${ }^{\circ} \mathrm{OCO}, 9 \mathrm{OSr}, 13 \mathrm{Cs}, 238,23 \mathrm{sPu}$ and $24 \mathrm{Am}$, as well as other radionuclides specifically mentioned in 10 CFR 61 (e.g., ${ }^{14} \mathrm{C}, 59 \mathrm{Ni}, 61 \mathrm{Ni}, 99 \mathrm{TC},{ }^{129 \mathrm{I}}$, were not detectable in these samples. These measurements verify that subsurf ace migration of radionuclides has occurred over limited distances within the Maxey Flats restricted area, but with the possible exception of tritium, subsurface migration to points outside the restricted area has not been a significant source of contamination by radionuclides of the environs adjacent to the Maxey Flats site.

During the reporting period work on this task work was concentrated on the analys is of samples and data from the Chalk River, Canada site. The work at Chalk River was initiated to allow field sampling to be conducted before winter weather conditions would prohibit field sampling. The sampling program used existing wells and sampling points established at Chalk River and was developed taking into consideration the hydrogeology annd stratigraphy of the site. It also considers the application of statistics in siting and manaing low-level radioactive waste disposal facilities. This work was undertaken at NRC's request, to initiate a new program. 
- Ecological Monjtoring at Commercial Shallow Land Burial Sites

Ecological field sampling performed at Maxey Flats has evaluated a broad spectrum of radionuclides in leaves, forest floor litter and surface soil but only $\boldsymbol{H}$ and ${ }^{6} \mathcal{C}_{0}$ appear to be derived from the disposal site. Even these radionuclides are at only slightly elevated levels, well below the MPC's for drinking water. These surveys indicate that leaf fall can be a cost-effective, efficient way to estimate the annual contribution of radionuclides to the forest floor of oakhickory forests. Tree sap and water from transpiring leaves have al so been collected and analyzed for tritium, and indicate that tritium uptake by deeprooted trees has potential to serve as a biamonitor of subsurface movement of water from burial sites. These surveys have indicated that biamonitors may be us eful as indicators of radionuclide migration from shallow land burial sites. Intensive tree leaf sampling around the Maxey Flats site has also demonstrated how the data may be used to establish locations for sampling wells in optimum positions for the detection of potential radionuclide migration .

Plans have been formulated for additional sap sampling and leaf water sampling during calendar year 1984. The samplings will be coordinated with the scheduled restart of the evaporator at Maxey $F 1$ ats, now set for April, 1984. Sampling will include samples taken before evaporator operation, during the initial stages of evaporator operation, and about six months af ter the start of evaporator operation.

\section{- Technical Program Coordination}

The report PNL $-4432-6$, "Chemical Species of Migrating Radionuclides at Commercial Shallow Land Burial Sites, Quarterly Progress Report, Jul y-September, 1983" was published and distributed in November, 1983.

The report NUREG/CR-3607, "Radi onuclide Distributions and Migration Mechanisms at Shallow Land Burial Sites: 1982 Annual Report of Research Investigations on the Distribution, Migration and Contaiment of Radionuclides at Maxey Flats, Kentucky", was submitted to NRC for publication(1). 
TABLE OF CONTENTS

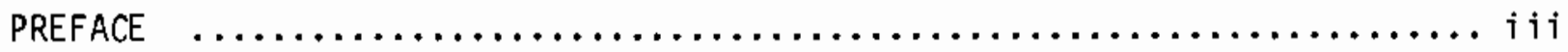

EXECUTIVE SUMMARY $\ldots \ldots \ldots \ldots \ldots \ldots \ldots \ldots \ldots \ldots \ldots \ldots \ldots \ldots \ldots \ldots \ldots \ldots$

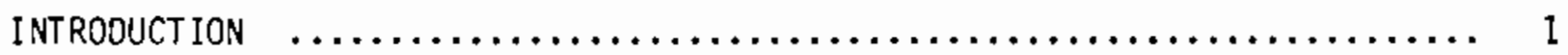

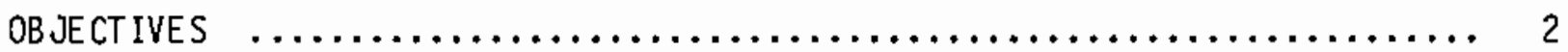

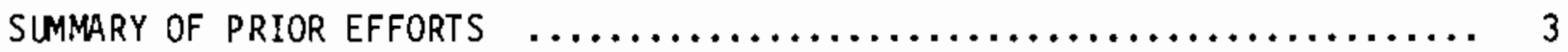

SIGNIFI CANT CURRENT RESEARCH RESULTS $\ldots \ldots \ldots \ldots \ldots \ldots \ldots \ldots \ldots \ldots \ldots \ldots$

Task A - Chemical Fonms: Inorganic and Organic Radionuclide Species $\ldots \ldots \ldots \ldots \ldots \ldots \ldots \ldots \ldots \ldots \ldots \ldots$

Task B - Subsurf ace Migration and Infiltration

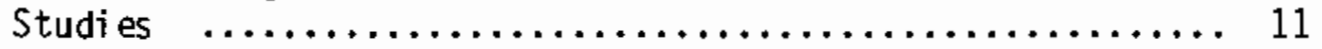

Task C - Specific Radionuclide Mapping at Maxey Flats and Other Commercial Shal Tow Land Burial Sites $\ldots \ldots \ldots \ldots \ldots \ldots$

Task D - Ecological Monitoring at Commercial Shallow Land Burial Sites ................................. 14

Task E - Technical Program Coordination for Low-Level

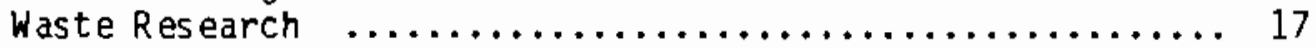

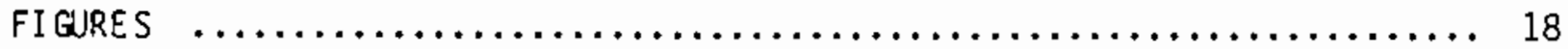

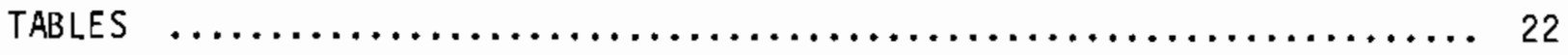

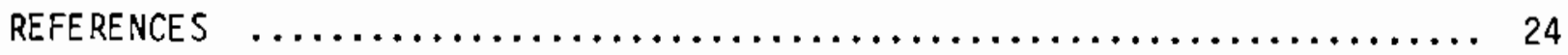





\section{INTRODUCTION}

One of the most important factors to be considered during the 1 ong-term isolation of radioactive wastes at commercial low level shallow land burial sites is the subsurface migration of radionuclides, which depends, among other things, on the chenical forms of the radionuclides. The oxidation state, ionic form, and the formation of complexes or chelates with organic ligands can markedly influence radionuclide migration. Therefore, determination of the precise chemical species of radionuclides that have migrated is essential for our accurate evaluation of the long-term performance of shallow 1 and burial sites. It is also essential to identify the organic and inorganic compounds and ionic species which are present in buried waste or can be generated in situ by chemi$c$ al reactions and subsequently participate in the formation of the chemical species that may be shown to migrate.

Pacific Northwest Laboratory (PNL) has assisted in coordinating the NRC research program at Maxey Flats since 1979 to establish and carry out a unified and comprehensive study of the problems specific to that site and to obtain generic information that may be useful in setting criteria for decomrissioning of existing commercial sites and for licensing of future commercial LLW burial sites. The objectives of this broad, multidisciplinary, multilaboratory program inctude determining:

- Radjochenical and chenical composition of leachates in waste burial trenches;

- Subsurface migration rates of radionuclides and the chenical, physical, biological, and hydrogeological factors which affect this migration;

- Areal distribution of radionuclides at commercial shal low land burial sites and the factors responsible for this distribution;

- Concentrations of radionuclides in vegetation both on and off site and the uptake of radionuclides by representative agricultural crops;

- Atmospheric patmays for radionuclide transport and the mechanisms involved; and

- Engineering practices which influence the seepage of surface waters into the burial trenches. 


\section{$\underline{\text { OBJECTIVES }}$}

The primary purpose of this project is to develop an understanding of the chemical processes that influence radionuclide migration at commercial LLW burial sites. Chemical measurements of waste trench leachate and identification of chemical changes in chemical forms that occur during migration are being made and will provide a basis for geochemical waste transport models. This project will produce for NRC information to support guidance for implementation of 10 CFR 61, particularly in the development of criteria for comercial LLW disposal site selection, management, permanent closure and monitoring.

Specific objectives of this project with respect to measurements to be made at existing sites are:

- Define the actual chenical species of the radionuclides which are migrating by subsurf ace routes;

- Identify the chemical characteristics of the trench leachate which retard or enhance radionuclide mobility;

- Determine the chemical changes in leachate properties which result from installation of infiltration barriers such as the flexible vinyl covers at Maxey Flats;

- Provide the chemical and radiochenical input parameters essential for hydrological/geochenical modeling of subsurface radionuclide transport;

- Detemine the factors responsible for the areal distributions of sur$f$ ace radionuclides and develop improved procedures for monitoring;

- Develop and test post-closure monitoring protocols that can be used at Maxey Flats and test the applicability of these protocols to operationa? and post-operational monitoring at other commercial sites; and

- Assist in coordinating LLW research projects for NRC.

Field measurements at shallow land burial sites provide unique opportunities to identify in actual waste burial situations the chemical and geochemical parameters which retard or enhance radionuclide mobility at LLW burial sites. 
The work at Maxey Flats aiso responds to the need for infomation on the areal distribution of radionuclides and the extent of subsurface transport of radionuclides at that site. This data base is needed by the Cammonweal th of Kentucky as they finalize plans to stabilize, close and monitor the Maxey Flats site.

\section{SUMMARY OF PRIOR EFFORTS}

Under this research program, PNL assists in coordinating NRC-sponsored LLW research, which has included PNL studies on chemical species and areal distributions of radionuclides, work on trench water chemistry by Brookhaven National Laboratory ( $B N L$ ), plant uptake studies by the University of CaliforniaLos Angeles, engineering studies by the University of Arizona, unsaturated flow studies by Los Alamos National Laboratory (LANL) and The University of California - Berkeley (UCB), and water and mass balance studies by the Commonweal th of Kentucky.

To conduct experiments for determining the subsurface transport of radionuclides from existing waste burial trenches at a comercial LLW site, two experimental areas were established within the Maxey Flats, Kentucky, LLW disposal facility. This required the cooperation of several national and state agencies, together with the NRC contractors, for successful implementation. These experimental areas included:

- An experimental slit trench installed during the 1 ast quarter of $F Y$ 1979 and first quarter of FY 1980; and

- Fourteen inert atmosphere sampling wells installed in undisturbed soil adjacent to the experimental slit trench during the last quarter of FY 1980. A comprehensive array of porous cups and soil moisture cells was also installed for the LANL and UCB programs.

The experimental areas have been described in NUREG/CR-1832, Section IV and NUREG/CR-2383, Section I and are j11ustrated in Figures 1 and 2 of this report. These experimental areas have supported research studies by PNL, LANL, UCB and BNL. 
The two experimental areas have enabled samples to be taken for the study of chemical species of radionuclides, saturated and unsaturated flow, nonradioactive tracer movement, trench cap engineering and drainage, plant uptake, and total water balance by the laboratories participating in research at Maxey Flats. These experiments have provided needed information on rates and mechanisms of subsurface transport of radionuclides from waste burial trenches by both saturated and unsaturated flow at the Maxey Flats site.

Field measurements have been performed by PNL at the Beatty, $\operatorname{Nevada}(9)$, and Maxey Flats, Kentucky, (NUREG/CR-2383, Section II and NUREG/CR-1832, Section IV) burial sites to help determine the areal distribution of radionuclides at these sites and the factors responsible for this distribution. Field measurements were also performed adjacent to the Maxey Flats facility, and confined that contamination is largely contained within the restricted area at this burial site. The areal distribution of radionuclides at Maxey Flats has been influenced by site operation and majntenance activities, surface contamination and runoff, deposition from the evaporator plume, and the actions of burrowing animals or deep-rooted trees. Vegetational and surface contamination on site and near site are quite low; of the gamm-ray-emitting radionuclides measured, only $6 \alpha_{0}$ exceeds commonly observed fallout levels. The average concentrations in surface soil at Maxey flats are comparable to concentrations resulting from nomal fallout in other areas of high rainfall. Tritium concentrations in water near the site have been influenced by surface runoff and by condensation from the evaporator plume.

Following analys is of trench leachates sampled in 0ctober, 1978 and November, 1979, Clevel and and Rees (8) concluded that except for leachate from waste trench 27 most of the plutonium in trench water is in true solution, in the tetravalent state, and exists in complexes with strong organic ligands. PNL research conducted in 1979 and 1980 (NUREG/CR-1832, Section IV) demonstrated that plutonium in water from the experimental trench and in waste trench 27 leachate was present in highly complexed, anionic, reduced (trivalent and tetravalent) species. Ethylenedianinetetraacetic acid (EDTA) is the major organic complexing component in waste trench 271 eachate, but other polar, water-soluble organic compounds are also present (NUREG/CR-2383, section I). 
Plutonium and EDTA co-elute during steric exclusion chromatography of Maxey Flats trench and well waters, and evidence points to the migration of plutoniuil within the site as an EDTA complex. Polar organic compounds (e.g. palmitic and stearic acids) may inf Tuence the migration of ${ }^{90} \mathrm{Sr}$ and ${ }^{137} \mathrm{Cs}$. These studies have demonstrated the need to determine the stability of the various chel ates and complexes under the conditions existing in waste trench water at Maxey Flats, the conditions under which complexes of plutonium, anericium, cobalt and strontium can be decomposed and/or sorbed on the geologic media, and the need to separate and measure the concentrations of hydrophilic organic complexing agents that may affect the migration of radionuclides present in waste trench leachate.

Comprehensive organic analyses performed on Maxey $F$ lats waste trench leachate, water from the experimental trench and water from the inert atmosphere wells have determined a large number of hydrophobic organic compounds in these waters(4). Analys is of the hydrophobic organic compounds that were isolated to facilitate the chromatographic analys is of hydrophilic organic species has also pemitted us to obtain information on toxic organic compounds that are present in these waters (3). Most of the hydrophobic organic compounds are present at parts-per-billion levels and only three of these compounds -pentafluorobenzoic acid (a non-radioactive tracer added to evaluate trench caps on the experimental trench), $2(3 \mathrm{H})$-benzothiazolone (present in waste trench 27 leachate) and a group of alkylphenoxy oligomers (present in inert atmosphere well W2NA) - are present at parts-per-mition levels. Two barbiturates, barbital and pentobarbital, were al so identified in water samples from waste trench 27 and inert atmosphere well W2NA.

Changes in tritium concentrations in water from the experimental trench and in inert tracers (e.g., sodium bromide) which were added to the trench (NUREG/CR-1832, pages IV-10 and IX-6) confint that subsurface flow does occur rather rapidly within the limited area of these experimental facilities. While increases in water level have occurred in the experimental trench, the absence of certain tracers in the water indicates that these increases have occurred without movement through the different trench caps installed on the five sections of the experimental trench (NUREG/CR-2383, Section I). 
Ecological field sampling perfomed at Maxey Flats (NLREG/CR-1832, Section $V$, and NUREG/CR-2383, Section III) has evaluated a broad spectrum of radionuclides in leaves, forest floor litter and surface soil, but only ${ }^{3} \mathrm{H}$ and ${ }^{60} \mathrm{Co}$ appear to be derived from the disposal site. Even these radionuclides are at only slightly elevated levels and are comparable to ambient fallout levels. Collections of freshly fallen tree leaves indicate that leaf fall collection is a cost-effective, nondestructive sampling procedure that $c$ an be incorporated into ecological monitoring programs to indicate migration or lack of migration from shallow land disposal sites. Tree sap and water from transpiring leaves have been collected and analyzed for tritium, indicating that tritium uptake by deeprooted trees has potential to serve as a biomonitor of subsurface movement of water from burial sites. The field surveys have indicated that biamonitors may be useful as indicators of radionuctide migration from shat low land burial sites.

Carbon-14 analyses of wood from selected trees adjacent to the Maxey Flats restricted area were compared with analyses from tree specimens at a location 12 miles from the Maxey Flats Facility. These limited data suggested that the site may have influenced ${ }^{14} \mathrm{C}$ levels very slightly at a few locations near the perimeter fence. The source of ${ }^{14} \mathrm{C}$ in the wood specimens is from carbon dioxide that is assimilated from air in the photosynthes is process $(3)$.

Remaining important areas of research include the fate of mobile (possibiy complexed) radionuclide species after leaving the trench enviroment, the control of these species within the commercial site boundaries, remedial action that $c$ an be taken to halt this mobility, and whether camplexing agents such as EDTA can be effectively destroyed in an aerobic environment.

Important observations from research conducted by PNL at Maxey Flats include:

- Identification of the magnitude of transport over short distances within the burial site by subsurface flow;

- Characterization of some of the important chemical species including plutonium-EDTA camplexes which are responsible for subsurface migration; 
- Identification of surface runoff from the site as a principal source for of $f$-site radionuclide accumulation in vegetation;

- Detemination of the off-site distribution of radionuclides at Beatty, Nevada, and Maxey Flats, Kentucky; and

- Establishent of the complexity and variability of waste trench leachates as source terms for the migration studies. (PNL research camplements the comprehensive analyses performed on waste trench leachate by BNL. See, for example, NUREG/CR-2383, Section IV, and NUREG/CR 1832, Section III.)

These research observations and related observations from the research performed at Maxey Flats by BNL, LANL, UCB, the University of Arizona and the University of $\mathrm{Cal}$ ifornia-Los Angeles are described in NUREG/CR -3607(1), NUREG/CR -2383(6) and NUREG/CR-1832(10).

\section{SIGNIFICANT CURRENT RESEARCH RESULTS}

This is the seventh quarterly report for the project "Chemical Species of Migrating Radionuclides at Commercial Shallow Land Burial Sites." The organization of these reports has undergone substantial change since the first report was issued in order to conform to revised research proposal formats requested by $\mathrm{NRC}$. We will continue to report and sumarize research results by subject and task.

Task A - Chemical Forms: Inorganic and Organic Radionuclide Species

The migration rates of radionuclides depend to a major degree on their chenical species. It is therefore extremely important that we determine chenical species in the waste burial trenches and in any water which has carried these radionuclides to our sampling points in the experimental trench and inert atmosphere sampling wells, or to springs some distances from the waste-filled trenches. In this task we are detemining as nearly as practicable the precise chemical forms for those radionuclides which are of greatest concern from an environmental and heal th standpoint. For example, plutoniom is present at Maxey Flats in waste trench leachate as a reduced 
(trivalent and tetravalent), anionic, highly complexed species. Similar identification will be made for other prevalent radionuclides. These include ${ }^{24 \mathrm{Am},}{ }^{60} \mathrm{Co},{ }^{137} \mathrm{Cs}$ and ${ }^{90} \mathrm{Sr}$, as well as other radionuclides specifically mentioned in 10 CFR 61 (e.g., $\left.{ }^{14} \mathrm{C},{ }^{59} \mathrm{Ni},{ }^{61} \mathrm{Ni},{ }^{99} \mathrm{Tc},{ }^{129} \mathrm{I}\right)$. The precise radiochemical and chemical parameters obtained from these studies will provide important basic infomation on the chemical species that develop under various buriat conditions. In these studies we will continue to supplement our laboratory work with on-site chenical separations employing tracers and organic ligand separations. The on-site separations minimize solution degradation and thereby duplicate as closely as possible actual field conditions.

During the previous quarter we performed a further analys is of the EDTATike species that were measured in waste trench leachates and inert atmosphere well water at Maxey Flats $(3,4,5)$. We had earlier identified three EDTA-like species of molecular weights 219,244 and 288 with structures similar to EDTA and related chelating agents (e.g. NTA, DTPA and HEDTA). We suggested that these EDTA-Tike species might be derived from the degradation of EDTA and assigned tentative structures to the EDTA-like species. Following additional detailed study, we concluded that the molecular weight 288 species is derived from the chel ating agent HEDTA and not from EDTA as previously assumed.

The detailed chemical speciation studies have demonstrated that EDTA is co-eluting with plutonium and ${ }^{6}{ }^{\circ} \mathrm{Co}$ during steric exclusion chromatography of water from waste trenches 27 and 195 and inert atmosphere well W2NA. Strontium-90 and ${ }^{137} \mathrm{Cs}$ al so appear to be associated with polar organic compounds, notably palmitic (hexadecanoic) and stearic (octadecanoic) acids. Quantitation of EDTA and of radionuclides in the concentrated and fractionated samples has demonstrated that the soluble plutonium is associated with EDTA.

Some of the plutonium originaliy present in the water samples is removed from the water during concentration of the samples by co-precipitation with iron. This occurs due to exposure to traces of oxygen or because the solubi1ity limits for iron have been exceeded in the concentrated samples. This observation suggests that uncomplexed plutonium will be fixed to the soil with the iron hydroxide precipitate when the anoxic groundwater is exposed to oxidizing conditions. 
During this quarter we have extended our analys is of the chelating agents reported previously(1-5). The most abundant hydrophilic organic compounds measured in the waste trench leachates were the chelating agents, which ranged in total concentrations fram $22.9 \mathrm{ppm}$ in trench $19 \mathrm{~W}$ to $0.08 \mathrm{ppm}$ in trench $33 \mathrm{~L}-$ 8. See Table 1 .

Three chelating agents were identified in the leachates: ethylenedianinetetraacetic acid (EDTA), N-hydroxyethylethylenediaminetriacetic acid (HEDTA), and ethylenedianinetriacetic acid (ED3A). EDTA is common to all of the leachates over a wide range of concentrations, ranging fran $12.4 \mathrm{ppm}$ in trench $19 \mathrm{w}$ down to $0.08 \mathrm{ppm}$ in trench $33 \mathrm{~L}-8$. EDTA is the most abundant chel ating agent in the leachates, with the exception of trench $23 M$ where HEDTA is most abundant. The relative abundance of EDTA in the leachates varies considerably: it constitutes $81 \%$ of the chelating agent pool in trench $7-3$ and only $17.3 \%$ in trench 23M. The differences undoubtedly reflect differences in the wastes originaliy buried, as well as differences in the microbial and/or chemical enviroments of the waste trenches.

Overa 11, HEDTA is the second most abundant chelating agent in the waste trenches. In trench $23 \mathrm{M}$ it is the most abundant hydrophilic organic compound at $19.5 \mathrm{ppm}$. This value is actually the highest for any of the chel ating agents. This overabundance of HEDTA, coupled with the unusually high concentration of ED3A, suggests that the waste buried in trench $23 \mathrm{M}$ is different than that of most of the waste trenches.

Analytically speaking, detection of HEOTA has presented a challenge. In early analyses of the waste trench leachates, we detected an unknown species of molecular weight (MW) 288 in the methylated hydrophilic organic fraction. On the bas is of GC-MS analys is, it clearly has an ethylenedianine core, but its MW did not correspond to any known chelating agent. Methylated HEDTA has a MN of 320. Careful interpretation of the GC-MS fragnentation pattern of the MW 288 species revealed the presence of a lactone ring suggesting that a hydroxyethyl group like that present in HEDTA might be responsible for the Iactone formation. GC-MS and MS analys is of methylated HEDTA subsequent?y revealed that indeed this compound gas chramatographs only as the MN 288 lactone species. 
The third chelating agent identified in the waste leachates is ED3A. It is the least abundant of the three chelating agents and is presumably a degradation product of HEDTA or EDTA, since EDTA has been reported to undergo environmental degradation to ED3A(11). ED3A does not appear to be commercially avai 1able as a chel ating agent but it could be present as a synthetic by-product of the commercial synthes is of HEDTA or EDTA.

The identification of ED3A also posed an analytical challenge. In the first round of analyses of the waste leachates, we identified an unknown species of MN 244 which we assumed to be derived from degradation of EDTA. However, with the aid of Fourier transform infrared analys is using a computerized infrared spectrophotometer interfaced wi th a gas chromatograph, we observed that the MW 244 species has a strong IR absorbance at $1690 \mathrm{~cm}^{-1}$, indicating the presence of a lactam ring. The structure that emerged is that of ED3A with one of its acetate ligands attached to a nitrogen of the ethylene-diamine core to form a lactam ring. This ring closure is probably a derivatization artifact caused by the heat $\left(100^{\circ} \mathrm{C}\right)$ used in the methylation procedure. The species which exists in the aqueous leachates is undoubtedly ED3A in the open, non1 act am form unless the waste had been heated, etc., prior to burial. See Figure 3 .

The absence of some of the chelating agents in certain leachates suggests differences in the waste originally buried or, perhaps, in the enviroment of the trenches. Leachate from trenches $7-3,27,33 \mathrm{~L}-4,33 \mathrm{~L}-8$, and 35 l ack HEDTA, presumably reflecting differences in the waste. Trenches $33 \mathrm{~L}-4,33 \mathrm{~L}-8$, and 35 a) so Tack ED3A. If ED3A is a degradation product of HEDTA or EDTA, our results indicate that is decomposition is not a simple process. The leachates that contain the most ED3A (trenches 19W, 19S, and 23M) al so contain both HEDTA and EDTA. However, two other samples which contain ED3A (trenches 7-3 and 27) contain only EDTA in addition. In three of the leachates (trenches $33 \mathrm{~L}-4$, $33 \mathrm{~L}-8$, and 35 ) EDTA is present without any ED3A.

The other hydrophilic organic compounds consist of a variety of carboxylic acids. Collectively, the carboxylic acids range in concentration from 8.8 ppm in trench 7-3 down to $0.7 \mathrm{ppm}$ in waste trench 27 . The dicarboxylic acids are the most abundant acids. One of these acids, oxalic acid, is used in nuclear 
decontamination operations but it is present only in leachate from waste trench 195 at a relatively low concentration of $0.1 \mathrm{ppm}$. The monocarboxylic acids are poorly represented in the waste leachates. Only two monocarboxylic acids were identified - hexadecanoic acid, commoniy known as palmitic acid and octagecanoic acid, commonly known as stearic acid. Groundwater samples typically contain these two compounds plus a variety of other monocarboxylic acids. The lack of monocarboxylic acids in the leachate samples undoubtedly reflects the fact that the water samples are relatively stagnant leachates of buried waste.

As a whole, the carboxylic acids are potential complexing agents of radionuclides, but any such association wuld be expected to be much weaker than the association of radionuclides and the chel ating agents. However, these bioorganic acids couid well constitute the precursors of fulvic and humic acids, which of ten comprise most of the bulk of the dissolved organic carbon (DOC) in groundwater and may be responsible for complexing radionuclides. The importance of such species to the complexation of radionuclides in groundwater is uncertain at this time, but should not be overlooked. Considerable research needs to be carried out on the role of the so-called "natural" organic compounds such as fulvic and humic acids in mobilizing or retarding radionuclide transport in soil solutions.

The hydrophobic organic compounds identified in waste trench leachates are summarized in Table 2. The concentrations of these compounds are generally much lower than those of the hydrophilic organic compounds (ppb vs ppm). A number of the compounds, e.g., the halogenated hydrocarbons, are toxic and of potential environmental concern. Their concentrations are quite low, however. From a research point of view, some of the hydrophobic organic compounds (e.g., the barbiturates) could be exploited as "in-situ," waste-derived tracers of groundwater flow and the amount of information potentially available justifies the research effort in analyzing the hydrophobic organic compounds.

Task B - Subsurface Migration and Infiltration Studies

The experimental trench and wells study was undertaken to determine if subsurface migration of radionuclides had occurred at Maxey $F 1$ at $s$, to measure the extent of any such migration, and to define the processes by which movement 
occurs. The work has utilized the experimental installations we established on the Maxey Flats site for defining migration rates and specific chemical species of long-lived fission products and the transuranium elements. It is also allowing the detemination of the chemical species of migrating nonradioactive elements associated with waste and utilizes non radioactive tracer movement to evaluate the effects of engineered trench caps and drainage systems on water infiltration rates.

Most samples from the porous cups, experimental trench sumps and inert atmosphere wells (Figure 2) have been collected on a monthly frequency, weather and water levels permitting. The water samples have been ana?yzed for ${ }^{3} \mathrm{H}$, gamma-ray enitting radionuclides (e.g., $\left.{ }^{60} \mathrm{Co},{ }^{137} \mathrm{Cs}\right)$, al pha-emitting radionuclides (e.g., 238,239,240 Pu, 24:Am), hydrophilic and hydrophobic organic species, and nonradioactive elements that can be determined by neutron activation $(\mathrm{e} . \mathrm{g} ., \mathrm{Br})$. These measurements verify that within the Maxey $\mathrm{Flat}$ s restricted area subsurface migration of radionuclides has occurred over limited distances (NLREG/CR-2383, page $1-13$ ). Except for tritium, migration to points outside the restricted area has not been a significant source of contamination by radionuclides. During the past quarter analys is of the water samples was suspended to permit the analysis of similar samples from Chalk River, Canada to proceed.

Well-logging of the inert atmosphere wells and experimental trench sumps (Figure 2) and of selected E-series wells (Figure 4) at Maxey Flats has confirmed that waste radionuclide migration along the sandstone marker bed occurred only within the restricted area. Cesium- $137\left(0.84 \mathrm{pCi} / \mathrm{gm}\right.$ of soil) and ${ }^{60} \mathrm{Co}(0.54$ $\mathrm{pC} i / g n$ of soil) were measured in well $14 \mathrm{E}$ on the Maxey Flats site at the top of the sandstone marker bed, or about 6.1 meters (20 feet) below the ground surface. The concentrations observed are below the concentrations measured in surface distribution studies (NLREG/CR-2383, Section II and NIREG/CR-1832, Section IV). Naturally-occurring radionuclides quantified included ${ }^{226} \mathrm{Ra}(0.99$ $\mathrm{pCi} / \mathrm{gm}),{ }^{23}{ }^{2} \mathrm{Th}(1.2 \mathrm{pCi} / \mathrm{gm})$ and ${ }^{40} \mathrm{~K}(10 \mathrm{pCi} / \mathrm{gm})$. Strontium-90 is a 30 present at or below the detection Timit by well-logging techniques ( $\leqq 10 \mathrm{pCi} / \mathrm{gm}$ of soil). We are continuing our efforts to quantify the $905 r$ concentration at this location.

Ouring the past quarter work on this task was concentrated on the analys is of samples and data from the Chalk River, Canada site. The work being conducted 
at Chalk River is part of a new proposal subritted to NRC entitled "Chenical Species of Migrating Radionuclides from Low Level Waste Disposal Sites," FIN 82862. A portion of this work is included herein at the request of NRC to implement FIN B2862 to allow field work to be conducted at Chalk River before winter weather conditions prohibited field sampling. The field sampling program utilizes existing wells and sampling points at Chalk River. The sampling program was developed taking into consideration the hydrogeology and stratigraphy of the site and in consideration of the application of statistics in siting and managing low-level radioactive waste disposal facilities.

Task C - Specific Radionuclide Mapping at Maxey Flats and Other Commercial Shallow Land Burial Sites

The Maxey Flats burial site has been contaminated by several sources. These include the overflow of water from the burial trenches as rainwater infiltrated and filled them, spillage during pumping of excess water from the trenches, fallout from entrained radionuclides in the evaporator $p l u m e$, and surface runoff of radioactive solutions from the site. To obtain a better understanding of the actual sources of radioactivity in surface soils and vegetation on the burial sites and adjacent areas, a detailed study of the levels of radioactivity has been underway at Maxey Flats and related studies should also be useful at other commercial shallow land burial sites.

In situ gamma ray surveys conducted at the Beatty, Nevada(9) and Maxey Flats, Kentucky (NUREG/CR-2383, Section II and NUREG/CR-1832, Section IV) shallow land burial sites confinmed that most of the waste radionuclides have been retained within the boundaries of those sites. The in situ measurements were correlated with and augmented by analysis of samples taken from each of the counting locations, since only the more energetic gamma ray enitting radionuclides are measured by the in situ procedures.

Slightly elevated tritium concentrations in water samples from springs and seeps outside the Maxey Flats restricted area suggested that other radionuclides might also be slightly elevated at these locations. However, all gamma-ray measurements have indicated that ${ }^{60} \mathrm{Co}$ and ${ }^{13}{ }^{7} \mathrm{Cs}$ are present at ambient fallout levels. Strontium-90 and $238,239,240 \mathrm{pu}$ were also at anbient fallout levels, as determined from radiochemical separation and analys is of aliquots 
of soil and water. The measurements indicate that radionuclide migration to these springs and seeps is not occurring, except possibly for tritium.

These studies have demonstrated that surface contamination by radionuclides $h$ as been retained mainly within the restricted area at Maxey Flats. Surface sediments in areas adjacent to the site, primarily on the west side, contain $60 \mathrm{Co}$ in concentrations greater than fallout. The origin of the $60 \mathrm{Co}$ is from surface runoff into the adjacent woods. Measurements made to date indicate that of fsite contamination has not resulted from subsurface transport, except possibly for tritium. The relative contributions of tritium from air (evaporator output), surface and subsurface pathways are being further evaluated during the second six-month curtailment of evaporator use by the Comonwealth of Kentucky prior to submission of a topical report summarizing the areal distribution studies.

Task D - Ecological Monitoring at Commercial Shallow Land Burial Sites

In this task we are developing efficient and statistically valid ecological field sampling procedures and methods for post-closure monitoring at shallow land burial sites. Kinds and amounts of radionuclides and trace elements in environmental samples are being measured with emphas is on biotic uptake, bioaccumulation, biotic transport, and ecological pathways in semi-wild ecosystems. We are emphasizing the sampling for pattern approach to provide three dimensional data that are amenable to rigid statistical analys is.

Forest sampling at Maxey Flats indicates the presence of a broad spectrum of naturally occurring and fallout-derived radionuclides in the litter layers, surface soit, and in freshly fal len autumn leaves (7). Radiochemical analyses of garma-ray emitting radionuclides show very low levels of all radionuclides and only ${ }^{\circ} \mathrm{C}$ o was elevated above ambient fallout levels and is most likely of disposal site origin. Collections of freshly fallen tree leaves indicate that leaf fall collection is a cost-effective, nondestructive sampling procedure that can be incorporated into ecological monitoring programs to indicate migration or lack of migration from shal low land disposal sites. 
Tree sap and water from transpiring leaves have also been collected and analyzed for tritium; the results indicate that tritium uptake by deep-rooted trees likewise has potential to serve as a biamonitor of subsurface movernent of water from burial sites. Tritium is enviromentally one of the most mobile of radionuclides and it can move as tritiated water, as vapor, or in surface or groundwater flows. Trees obtain water from their rooting substrate and move it from roots to stems to leaves, and release water to air as vapor. Water can be extracted from fresh tree leaves and analyzed for tritium. If tritium is present in the root zone, it appears in the extracted water. Bec ause trees have deeply penetrating roots, as compared to crop plants, they can be used to monitor subsurface water flows. Leaf water data indicate that tritium in above ambient fallout levels is present within the edge of the forest at Maxey $F$ lats $(2,5)$. Maple trees, Acer sacharum, have the unusual ability to move water through their trunk before new leaves emerge in the spring. If maple tree roots have access to tritiated water, tritium will appear in the sap stream. Experience at Maxey Flats indicates that sap samples for tritium analyses can be obtained by tapping tree trunks in a cost-effective and a biologically nondestructive fashion useful for post closure ecological monitoring programs.

Aut umn leaf-fall samples were collected from the $0.5 \mathrm{~m}^{2}$ rectangular wire baskets placed beneath the permanently tagged trees adjacent to the Maxey Flats restricted area. These samples have been dried and shipped to our PNL facilities at Richland, Washington, for analys is by gamma-ray spectrometry. We have determined the exogenous radionuclides $\left(e . g .,{ }^{60} \mathrm{Co},{ }^{137} \mathrm{Cs}\right)$ and obtained information on endogeneous (e.g., ${ }^{7} \mathrm{Be},{ }^{40} \mathrm{~K},{ }^{226} \mathrm{Ra},{ }^{228} \mathrm{Th}$ ) radionuclides in some of the samples. Comparison of their radionuclide concentration with values reported from earlier sampling runs (NLREG/CR-2383, Section III, and NLREG/CR-1832, Section $V$ ) indicates again that buried waste radionuclides have not migrated into the forest adjacent to the Maxey $F$ lats site.

Maple trees have now been tapped at more than 50 locations around the Maxey Flats disposal site and two trees have been tapped at a control location in a similar forest type near Cave Run Lake, about 12 miles south of Maxey Flats. Tritium concentrations in tree sap ranged from below detection leve? 
to $290,000 \mathrm{pCi}$ per liter of tree sap. The highest values occurred in two trees located along the western side of the disposal site and the lowest values were measured near $C$ ave Run Lake, which represented fallout (background) tritium levels. Trees sampled in the vicinity of the disposal site generally had tritium values higher than fallout levels, with the highest concentrations being measured on the steep slope bordering the western side of the disposal site. In general, tritium values declined with increasing distance from the disposal site.

Several sampling trips have been made to evaluate the feasibitity of using extractable leaf water from tree species other than maple as an indicator of tritium migration. In addition to the trees sampled around the fence, transects have also been made from the fence westerly into Drip Springs Hollow. Background samples were taken near Cave Run Lake, about 12 miles south of the Maxey flats faciTity. Tritium concentrations in leaf water tended to decline as the growing season progressed $(2)$. The decline may be due to the additional time elapsing between samplings, extending the time since evaporator shutdown. Further dilution of the tritium contained in the groundwater that the trees were utilizing could have occurred during this time. The decline might also be an artifact of the unseasonably dry weather that prevailed at the Maxey Flats site during the most recent sampling periods.

Two trees sampled along the transect into Drip Springs Hollow contained much higher than nomal concentrations of tritium (up to $2.7 \times 10^{7} \mathrm{pCi} / \mathrm{l}$ ). Other trees near this location 50 meters downslope from the fenced area contained substantially lower tritium concentrations, indicating that the source of tritium tapped by these trees is highly localized. These trees may pinpoint an ideal location to establish a monitoring well outside the restricted area.

Plans have been formulated for additional sap sampling and leaf water sampling during calendar year 1984. The samplings witl be coordinated with the scheduled restart of the evaporator at Maxey Flats, now set for April, 1984. Sampling will include samples taken before evaporator operation, during the initial stages of evaporator operation, and about six months after the start of evaporator operation. 
Carbon-14 is present in the waste trenches at Maxey Flats and is one of the radionuclides of concern for ecological monitoring following site closure (10 CFR 61). Although ${ }_{14} \mathrm{C}$ has been widely used as a tracer in biological experiments, comparatively little is known about the root uptake of ${ }_{14} \mathrm{C}$ from soil or soil water. Carbon-14 analyses on selected samples of wood obtained from trees adjacent to the Maxey $F$ lats restricted area were compared with analyses from trees located about 12 miles south of Maxey Flats facility, in the Daniel Boone National Forest. These limited data suggest that the site may have inf luenced ${ }_{14} \mathrm{C}$ levels very slightly in a few locations near the perimeter fence, where ${ }_{14} C$ concentrations are slightly el evated above the "modern value," which is in the range of $8-8.5 \mathrm{pCi} / \mathrm{gm}$. The source of ${ }_{14} \mathrm{C}$ in wood is from carbon dioxide assimilated from air in the photosynthes is process.

Task E - Technical Program Coordination for Low-Level Waste Research

The report PNL-4432-6, "Chemical Species of Migrating Radionuclides at Commercial Shal low Land Burial Sites, Quarterly Progress Report, JulySeptember, 1983" was published and distributed in November, 1983.

The report NUREG/CR-3607, "Radi onucl ide Distributions and Migration Mechanisms at Shallow Land Burial Sites: 1982 Annual Report of Research Investigations on the Distribution, Migration and Contaiment of Radionuclides at Maxey Flats, Kentucky", was submitted to NRC for publication(1). 


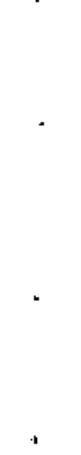




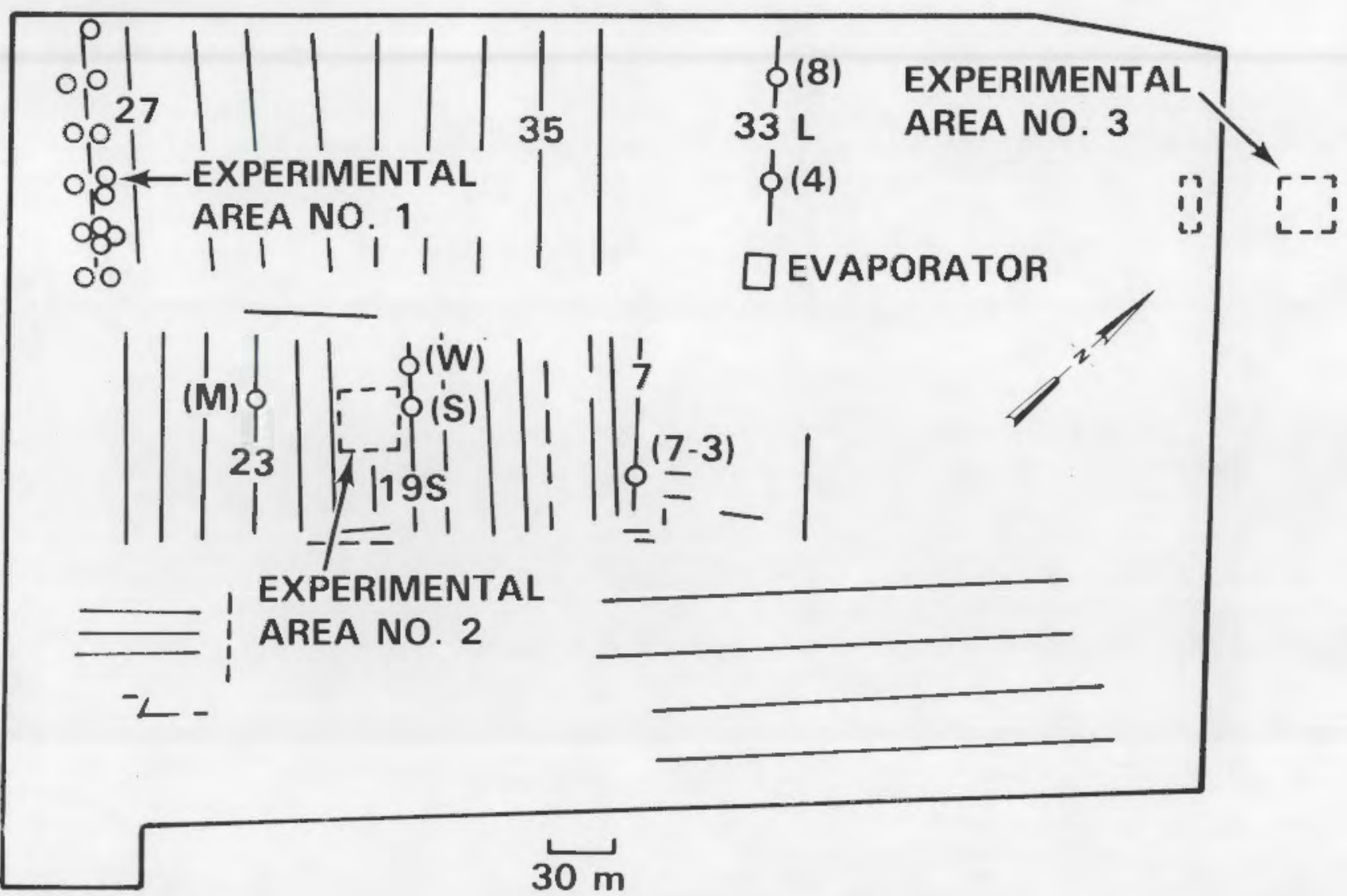

FIGURE 1. Maxey flats waste trenches and experimental areas. The numbered lines show the locations of selected waste trenches and numbers and letters in parentheses indicate the locations of sumps. Experimental area number 1 includes the experimental trench and inert atmosphere wells. Experimental area number 2 includes the porous cup and tensiometer installations for studying water movement in the burial area. Experimental area number 3 includes the UCB lysimeter installations for water balance studies. These experimental areas support research studies by PNL, LANL. UCB and BNL. 


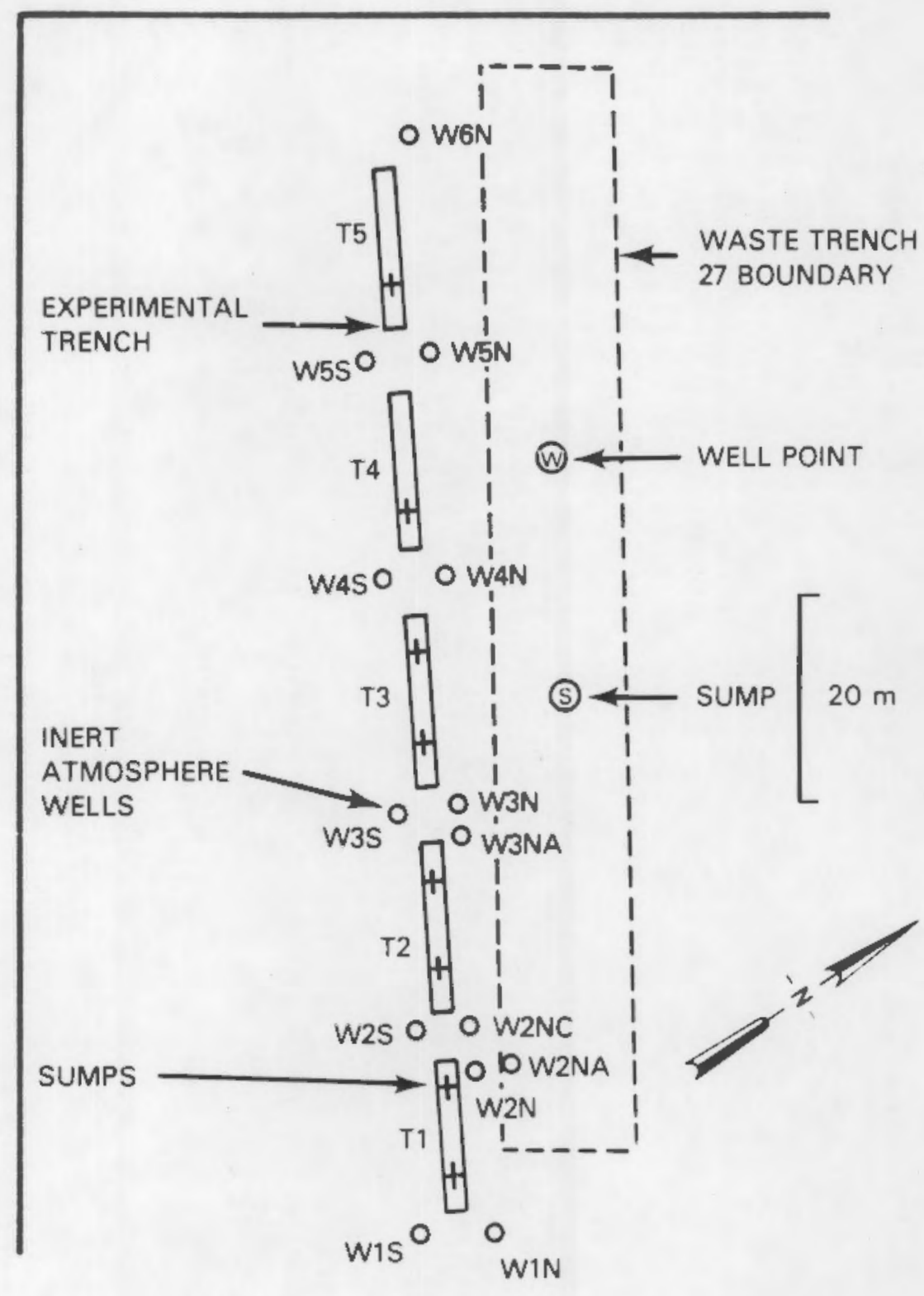

FIGURE 2. Maxey Flats Experimental Area No. 1, containing the experimental trench and wells near waste trench 27 . These facilities allow concurrent sampling of the experimental trench, inert atmosphere wells and adjoining waste trench for PNL groundwater migration and chemical species studies. The experimental trench is also used by LANL. UCB, and BNL in research studies at the Maxey Flats Shallow Land Burial Site. 


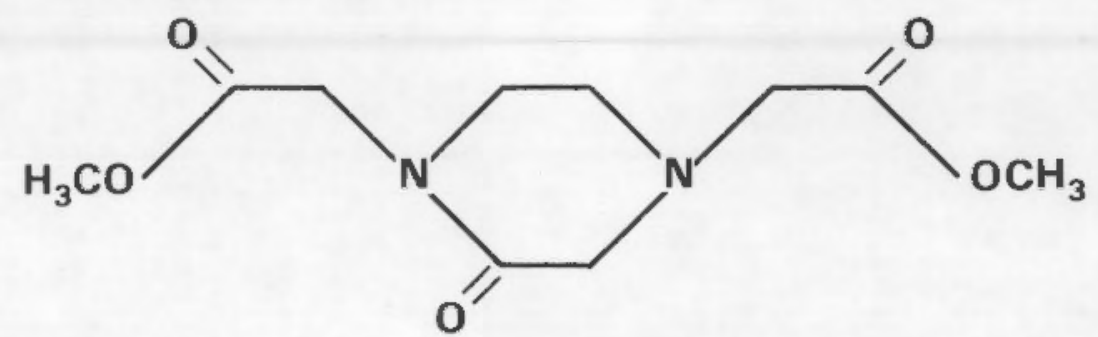

个 $\mathrm{BF}_{3} /$ METHANOL

$\triangle$

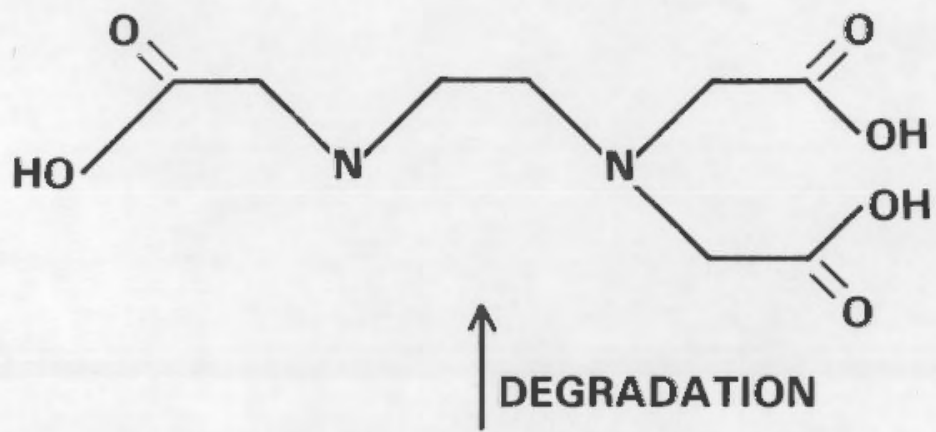

HEDTA OR EDTA
*MW 244 SPECIES

(METHYLATED)

ED3A

\section{*DETECTED BY GC-MS}

FIGURE 3. Formation of the molecular weight (MW) 244 species during analysis of Maxey Flats waste trench leachates. Ethylenediaminetriacetic acid (ED3A) is formed in the trenches by degradation of HEDTA or EDTA. Ring closure to form the MW 244 species containing the lactam ring occurs during methylation of the ED3A. 


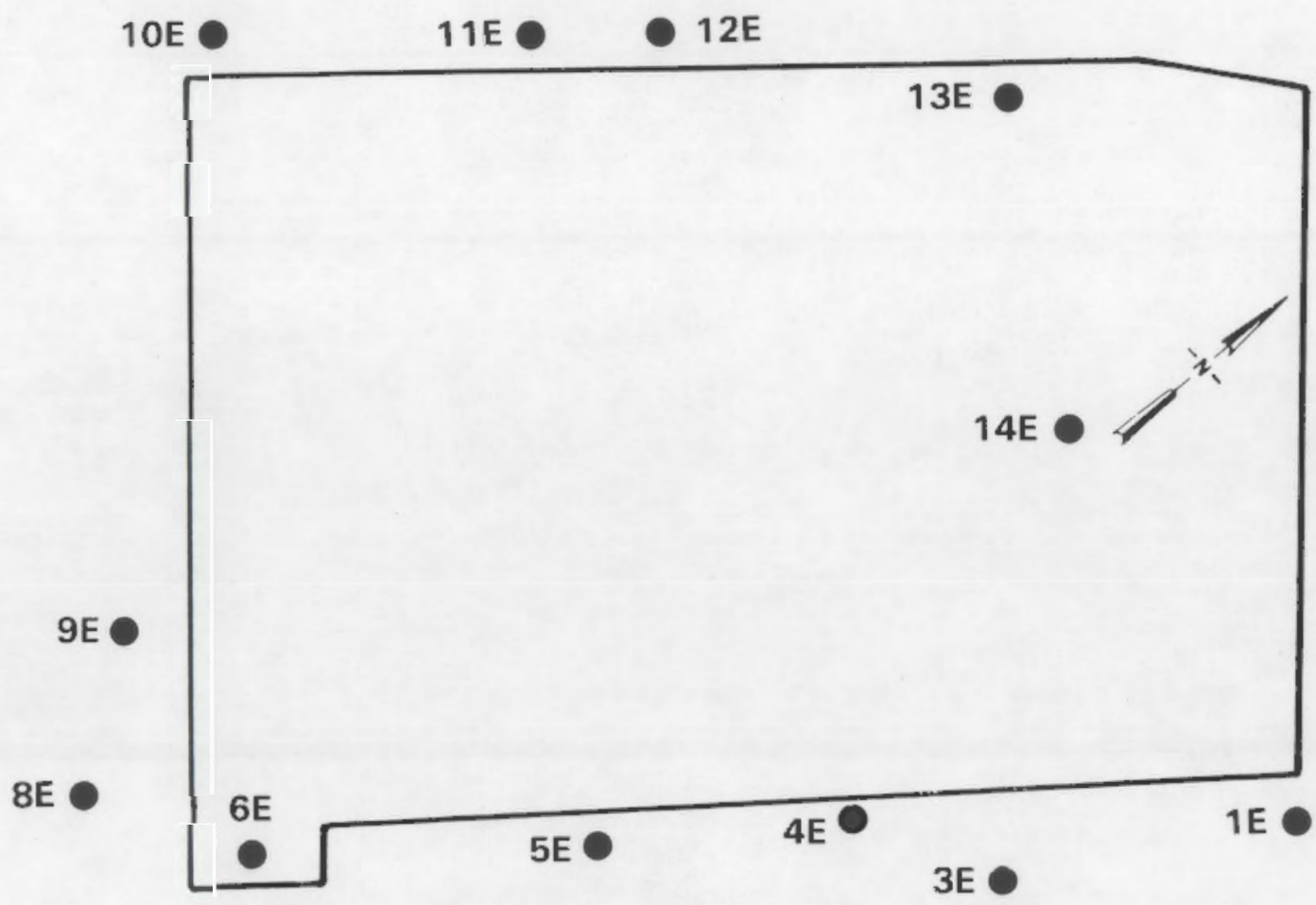

FIGURE 4. Locations of the E-series wells around the Maxey Flats restricted area. Three four-inch diameter wells - 13E, 14E and 3E - were logged and only $14 \mathrm{E}$ showed evidence of the presence of waste-derived radionuclides, e.g. ${ }^{137} \mathrm{Cs},{ }^{60} \mathrm{Co}$ and ${ }^{90} \mathrm{Sr}$. These radionuclides had migrated short distances within the restricted area along the sandstone marker bed. 
TABLE 1

Hydrophilic Organic Compoundsa in Waste Leachates from Maxey Flats

\begin{tabular}{|c|c|c|c|c|c|c|c|c|}
\hline & \multicolumn{8}{|c|}{ Waste Trenches $(\rho p b)^{b, c}$} \\
\hline & $7-3$ & $19 \mathrm{~W}$ & 195 & $23 \mathrm{M}$ & 27 & $33 L-4$ & $33 L-8$ & 35 \\
\hline \multicolumn{9}{|l|}{ Chelating Agents } \\
\hline $\begin{array}{l}\text { Ethylenediaminetetraacetic } \\
\text { Acid (EDTA) }\end{array}$ & 5,016 & 12,364 & 4,261 & 4,895 & 962 & 402 & 78 & 868 \\
\hline \multicolumn{9}{|l|}{ N-Hydroxyethylethylene- } \\
\hline diaminetriacetic Acid (HEDTA) & & 8,350 & 888 & 19,511 & & & & \\
\hline $\begin{array}{l}\text { Ethylenediaminetriacetic Acid (ED3A) } \\
\text { Dicarboxylic Acids }\end{array}$ & 1,195 & 2,190 & 823 & 3,884 & 212 & & & \\
\hline \multicolumn{9}{|l|}{ Dicarboxylic Acids } \\
\hline $\begin{array}{l}\text { Oxalic Acid } \\
\text { Succinic Acid }\end{array}$ & & & 111 & & & & & \\
\hline Succinic Acid & 345 & & 92 & & 26 & 630 & 39 & 80 \\
\hline Methylsuccinic Acid & 191 & & & & 21 & & 21 & 231 \\
\hline Pentanedioic Acid & 248 & & & & 41 & & 54 & 406 \\
\hline Hexanedioic Acid & 1,569 & 223 & 226 & 244 & 167 & 451 & 104 & 834 \\
\hline $\begin{array}{l}\text { Methylhexanedioic Acid } \\
\text { Octanedioic Acid }\end{array}$ & & & & & & 781 & 57 & 305 \\
\hline Nonanedioic Acid & 455 & 338 & 610 & 210 & 96 & 1,394 & 111 & 314 \\
\hline \multicolumn{9}{|l|}{ Monocarboxylic Acids } \\
\hline Hexadecanoic Acid & & & & & & & 61 & \\
\hline Octadecanoic Acid & & & & & & 31 & 111 & \\
\hline \multicolumn{9}{|l|}{ Oxygenated Acids } \\
\hline \multirow{2}{*}{\multicolumn{7}{|c|}{ Aromatic Acids }} & & 185 \\
\hline Benzoic Acid & & & 635 & & & & & \\
\hline 2-Hydroxybenzoic Acid & & & & & & & 27 & \\
\hline 1,3-Benzenedicarboxylic Acid & 381 & 276 & & 440 & 77 & & & 877 \\
\hline 1,4-Benzenedicarboxylic Acid & 1,181 & 162 & & 457 & & & & 1,139 \\
\hline $\begin{array}{l}\text { 1,2,4-Benzenetricarboxylic Acid } \\
\text { Phthalates }\end{array}$ & \\
\hline Dimethyl Phthalate & 8,817 & 2,836 & 1,772 & 1,673 & & & 98 & 13,565 \\
\hline Methylpropyl Phthalate & & 213 & & 108 & 12 & & & 874 \\
\hline Dioctyl Phthalate & & & & & 851 & & & \\
\hline
\end{tabular}

a) Methylated $\left(\mathrm{BF}_{3} /\right.$ Methanol), acids identified as methyl esters;

b) No entry indicates compound is below detection levels;

c) Samples collected by BNL in 10/81, except for Trench $27(10 / 79)$; 19 S collected by PNL on $7 / 22 / 82$;

d) Identified as Lactam (MW 244). 
TABLE 2

Hydrophobic Organic Compounds in Waste Leachates from Maxey Flats

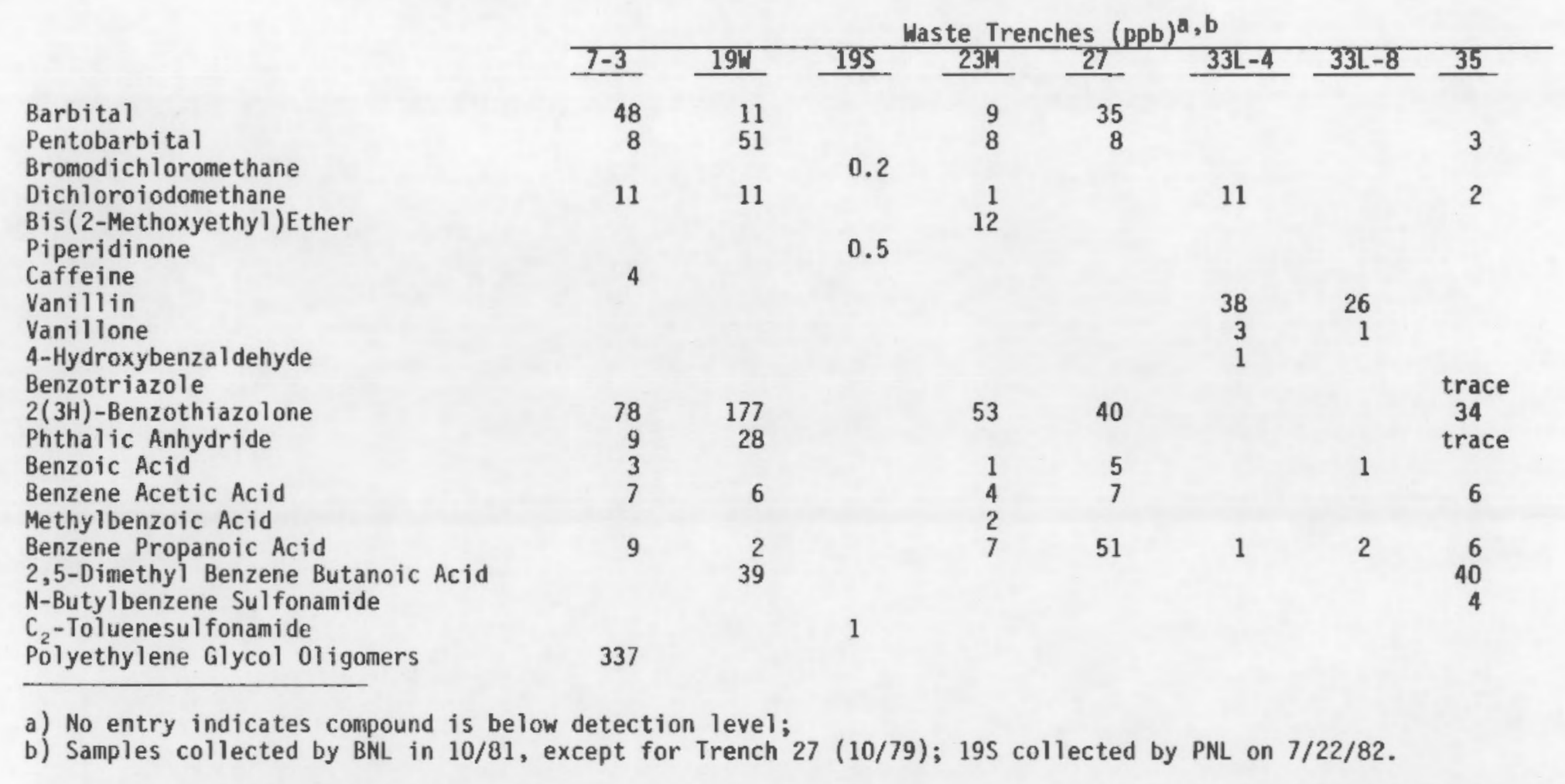




\section{REFERENCES}

1. L. J. Kirby, Ed., "Radionuclide Distributions and Migration Mechanisms at Shallow Land Burial Sites: 1982 Annual Report of Research Investigations on the Distribution, Migration and Contaiment of Radionuclides at Maxey Flats, Kentucky," NUREG/CR-3607, 1984 (in press).

2. L. J. Kirby, W. H. Rickard and A. P. Toste, "Chenical Species of Migrating Radionuclides at Commercial Shallow Land Burial Sites, Quarterly Progress Report, Jul y-Sept ember, 1983, PNL-4432-6, November, 1983.

3. L. J. Kirby, A. P. Toste and W. H. Rickard, "Chemical Species of Migrating Radionuclides at Commercial Shallow Land Burial Sites, Quarterly Progress Report, April-June, 1983," PNL-4432-5, July, 1983.

4. L. J. Kirby, W. H. Rickard and A. P. Toste, "Chemical Species of Migrating Radionuclides at Commercial Shallow Land Burial Sites, Quarterly Progress Report, January-March, 1983," PNL-4432-4, Apri 1, 1983.

5. L. J. Kirby, A. P. Toste and W. H. Rickard, "Chenical Species of Migrating Radionuclides at Commercial Shallow Land Burial Sites, Quarterly Progress Report, October-Decenber, 1982," PNL-4432-3, March, 1983.

6. L. J. Kirby, Ed., "Radi onuclide Distributions and Migration Mechanisms at Shallow Land Burial Sites: Annual Report of Research Investigations on the Distribution, Migration and Contaiment of Radionuclides at Maxey Flats, Kentucky," NUREG/CR-2383, 1982.

7. W. H. Rickard, L. J. Kirby and M. C. McShane, "Gamma Emitting Radionuclides in a Deciduous Forest Surrounding a Shallow Land Burial Site in the Eastern United States," IAEA-SM-257-67P, International Symposium on Migration in the Terrestrial Environment of Long-Lived Radionuclides from the Nuclear Fuel Cycle, Knoxville, Tennessee, July 27-31, 1981.

8. J. M. Cleveland and T. F. Rees, "Characterization of Plutonium in Maxey Flats Radioactive Trench Leachates," Science 112, 1506 (1981).

9. H. L. Nielson, N. A. Wogman and L. J. Kirby, "Field Survey of the Shal low Land Low-Level Radioactive Waste Burial Site Near Beatty, Nevada," in The State of Waste Isolation in the U.S. and Elsewhere, Advocacy Program and Public Communications, M. E. Wacks and R. G. Post, Eds., Vol ume 2, pp. $707-719,1981$.

10. L. J. Kirby, Ed., "Research Program at Maxey Flats and Consideration of Other Shallow Land Burial Sites," NUREG/CR-1832, 1981.

11. H. B. Lockhart, Jr. and R. V. Blakely, "Aerobic Photodegradation of Fe(III)(Ethylenedianitrilo) Tetraacetate (Ferric EDTA)", Environ. Sci. Tech. 58 (19), 1999 (1980). 

PNL -4432-7

\section{DISTRIBUTION}

No. of

Copies

\section{OFFSITE}

7 E. O'Donnell

U.S. Nuclear Regul atory Commission

Office of Nuclear

Regul atory Research

Mail Stop 1130 SS

Washington, D.C. 20555

F. J. Arsenault

U.S. Nuclear Regulatory Conmission

Office of Nuclear

Regul atory Research

Mail Stop 1130SS

Washington, D.C. 20555

P. A. Comella

U.S. Nuclear Regul at ory Commission

Office of Nuclear Regul at ory Research

Mail Stop 1130SS

Washington, D.C. 20555

E. F. Conti

U.S. Nuclear Regul at ory Commission

Office of Nuclear Regul at ory Research

Mail Stop 1130 SS

Washington, D.C. 20555

M. J. Bell

U.S. Nuclear Regulatory Commission

Office of Nuclear Material Safety and Safeguards

Mail Stop 697SS

Washington, D.C. 20555
No. of

Copies

R. E. Browning

U.S. Nuclear Regulat ory Commission

Office of Nuclear Material Saf ety and Safeguards

Mail Stop 697SS

Washington, D.C. 20555

L. B. Higginbotham

U.S. Nuclear Regul atory Commission

Office of Nuclear Material Saf ety and Safeguards

Mail Stop 697SS

Washington, D.C. 20555

K. Jackson

U.S. Nuclear Regul at ory Commission

Office of Nuclear Material Saf ety and Safeguards

Mail Stop 697SS

Washington, D.C. 20555

P. Ohaus

U.S. Nuclear Regulat ory Commission

Office of Nuclear Material Saf ety and Safeguards

Mail Stop 6975S

Washington, D.C. 20555

J. F. Kendig

U.S. Nuclear Regulat ory Commission

Office of State Programs

Mail Stop AR5235

Washington, D.C. 20555 
PNL $-4432-7$

DISTRIBUT ION

No. of

Copies
G. F. Birchard
U.S. Nuclear Regul atory Commission
Division of Saf eguards, Fuel Cycle and Enviromental Research
Mail Stop 1130ss
Washington, D.C. 20555
D. H. Alexander
U.S. Nuclear Regulatory Commission
Division of Saf eguards, Fuel
Cycle and Environmental Research
Mail Stop 1130 SS
Washingt on, D.C. 20555
D. Brooks
U.S. Nuclear Regulatory Comnission
Office of Nuclear Material $S$ af ety and Safeguards
Mail Stop 697SS
Washington, D.C. 20555
W. Kelly
U.S. Nuclear Regulat ory Commission
Office of Nuclear Material
Saf et $y$ and $S$ af eguards
Mail Stop 697SS
Washington, D.C. 20555
R. J. Starmer
U.S. Nuclear Regul atory Commission
Office of Nuclear Material
Saf et $y$ and $S$ af eguards
Mail Stop 697SS
Washington, D.C. 20555

No. of

Copies

2 U.S. Nuclear Regulatory Commission

Division of Technical Information and Document Control

7920 Norfolk Avenue

Bethes da, MD 20014

Document Control Center

U.S. Nuclear Regul atory Commission

Office of Nuclear Material $S$ af ety and Safeguards

Mail Stop 697SS

Washington, D.C. 20555

2 DOE Technical Information Center

P.0. Box 62

Oak Ridge, TN 37830

M. J. Barainca

U.S. Department of Energy 550 Second Street

Idaho $\mathrm{Fal1s}$, ID 83401

E. A. Jennrich

U.S. Department of Energy 550 Second Street

Idaho Falls, ID 83401

E. A. Jordan

U.S. Department of Energy

Washington, D.C. 20545

R. Watters

U.S. Department of Energy

Washington, D.C. 20545

D. E. Large

U.S. Department of Energy

Box E

Oak Ridge, TN 37830 


\section{DISTRIBUTION}

No. of

Copies

L. J. Mezga

U.S. Department of Energy

Box X. B1dg. 1505

Dak Ridge, TN 37830

Dr. D. C. Haney

Kentucky Geological Survey

University of Kentucky

311 Breckinridge $\mathrm{Hall}$

Lexington, KY 40506

Dr. W. D. Keller

Department of Geology

University of Missouri

Columbia, MO 65201

Dr. A. Kilinc

Department of Geology

University of $\mathrm{C}$ incinnati

Cincinnati, $\mathrm{OH} 45221$

Dr. S. Leung

Department of Geology

Eastern Kentucky University

Richnond, KY 40475

R. Daya 1

Brookhaven National Laboratory

Building 830

Upton, NY 11973

R. F. Pietrzak

Brookhaven $N$ ational Laboratory

Building 830

Upton, NY 11973

D. C. Schweitzer

Brookhaven $N$ ational Laboratory

Building 830

Upton, NY 11973
No. of

Copies

\author{
J. Albanese \\ New York Geological Survey \\ Empire State Plaza \\ Albany, NY 12234 \\ R. K. Schulz \\ University of $\mathrm{Cal}$ ifornia \\ Department of Soils and Plant \\ Nutrition \\ Berkeley, CA 94720 \\ 0. I. Oztunali \\ Dames and Moore \\ 20 Haarlem Avenue \\ White Plains, NY 10600 \\ P. L. Phelps \\ Lawrence Livermore National \\ Laboratory \\ P.0. Box 5504, L- 156 \\ Livermore, CA 94550 \\ W. L. Polzer \\ Los Alamos National Laboratory \\ Enviromental Science \\ P.0. Box 1663 \\ Los Alamos, NM 87545 \\ A. L. Knight \\ U.S. Geological Survey, W.R.D. \\ Room 572 Federal Building \\ 600 Federal P lace \\ Louisville, KY 40202 \\ J. Fischer \\ U.S. Geological Survey \\ Office of Radiohydrology \\ $\mathrm{Nat}$ ional Center MS 410 \\ Reston, VA 22092
}


PNL-4432-7

\section{DISTRIBUTION}

No. of

Copies

J. B. Robertson

U.S. Geological Survey

Office of Radiohydrology

National Center MS 410

Reston, VA 22092

T. Tamura

Union Carbide Corporation

Oak Ridge National Laboratory

P.0. Box X

Oak Ridge, TN 37830

2 H. D. Mills

Department for Natural

Resources and Environmenta1

Protection

Fort Boone Plaza

18 Reilly Road

Frankfort, KY 40601

J. E. Razor

Hittman Nuclear Development Corporation

Route 2, Box 238A

Hillsboro, KY 41049

D. T. Clark

Department for Human Resources

Commonwealth of Kentucky

275 East Main Street

Frankfort, KY 40601

W. Hipsher

U.S. Ecology, Inc.

9200 Shelbyville Road, Suite 526

Louisville, KY 40207

A. Armbrust

U.S. Ecology, Inc.

P.0. Box 158

Sheffield, IL 61361
No. of

Copies

D. D. Ed

Illinois Department of Nuclear Safety

1035 Outer Park Drive

Springfield, IL 62704

\section{ONSITE}

39 Pacific Northwest Laboratory

L. L. Eberhardt

M. G. Foley

E. A. Jenne

L. J. Kirby (15)

J. M. Latkovich

J. M. Nielsen

R. W. Perkins

S. R. Peterson

W. H. Rickard

D. E. Robertson

J. L. Swanson

C. W. Thomas

J. M. Thomas

A. P. Toste

C. M. Unruh

W. R. Wiley

R. E. Wildung

N. A. Wogman

Technical Information (5)

Publishing Coordination (2) 